\title{
Retraction \\ Retracted: Comparison of Two Entry Methods for Laparoscopic Port Entry: Technical Point of View
}

\author{
Diagnostic and Therapeutic Endoscopy
}

Received 14 September 2020; Accepted 14 September 2020; Published 21 December 2020

Copyright (C) 2020 Diagnostic and Therapeutic Endoscopy. This is an open access article distributed under the Creative Commons Attribution License, which permits unrestricted use, distribution, and reproduction in any medium, provided the original work is properly cited.

Diagnostic and Therapeutic Endoscopy has retracted the article titled "Comparison of Two Entry Methods for Laparoscopic Port Entry: Technical Point of View" [1]. In the article as a whole $942 / 4808$ words are original $(20 \%)$ and $80 \%$ of the article text is reproduced from 20 previously published articles by other authors, most but not all of which were cited. The main sources are as follows:

(1) Afifi, Y., A. Raza, M. Balogun, K. S. Khan, and R. Holders. "New nomogram for safe laparoscopic entry to reduce vascular injury", Journal of Obstetrics and Gynaecology, 2011, Volume 31, 2011-Issue 1. DOI 10.3109/ 01443615.2010.529517 http://www.tandfonline.com/doi/ full/10.3109/01443615.2010.529517. [2] (This was cited as reference 20)

(2) Azevedo, Otávio Cansanção de, Azevedo, João Luiz Moreira Coutinho, Sorbello, Albino Augusto, Miguel, Gustavo Peixoto Soares, Wilson Junior, Jorge Luiz, \& Godoy, Antônio Cláudio de. (2006). Evaluation of tests performed to confirm the position of the Veress needle for creation of pneumoperitoneum in selected patients: a prospective clinical trial. Acta Cirurgica Brasileira, 21(6), 385-391 DOI: 10.1590/S0102-86502006000600006. http:// www.scielo.br/scielo.php?script=sci_arttext\&pid=S0102-8 6502006000600006. [3] (This was cited as reference 41)

(3) S. Krishnakumar and P. Tambe, "Entry complications in laparoscopic surgery," Journal of Gynecological Endoscopy and Surgery, vol. 1, no. 1, pp. 4-11, 2009. http://www.gynecendoscopy.org/article.asp?issn=0974-1 216 ; year $=2009$; volume $=1$; issue $=1$; spage $=4$; epage $=11$; aulast=Krishnakumar. [4] (This was cited as reference 2)

(4) George A. Vilos, Artin Ternamian, Jeffrey Dempster, Philippe Y. Laberge, "Laparoscopic Entry: A Review of Techniques, Technologies, and Complications" SOGC
CLINICAL PRACTICE GUIDELINE, Journal of Obstetrics and Gynaecology Canada, Volume 29, Issue 5, May 2007, Pages 433-447 https:/www.sciencedirect. com/science/article/pii/S1701216316354962/https://sogc. org/wp-content/uploads/2013/01/gui193ECPG0705wDis claimer.pdf. [5] (This was not cited)

(5) O. H. M. Hypólito, J. L. M. C. Azevedo, F. M. S. De Lima Alvarenga Caldeira et al., "Creation of pneumoperitoneum: noninvasive monitoring of clinical effects of elevated intraperitoneal pressure for the insertion of the first trocar," Surgical Endoscopy and Other Interventional Techniques, vol. 24, no. 7, pp. 1663-1669, 2010. https://link.springer.com/article/10.1007\%2Fs00464-009 -0827-2. [6] (This was cited as reference 39)

\section{References}

[1] A. Toro, M. Mannino, G. Cappello, A. Di Stefano, and I. Di Carlo, "Comparison of two entry methods for laparoscopic port entry: technical point of view," Diagnostic and Therapeutic Endoscopy, vol. 2012, Article ID 305428, 7 pages, 2012.

[2] Y. Afifi, A. Raza, M. Balogun, K. S. Khan, and R. Holders, "New nomogram for safe laparoscopic entry to reduce vascular injury," Journal of Obstetrics and Gynaecology, vol. 31, no. 1, p. 69, 2011.

[3] O. C. d. Azevedo, J. L. M. C. Azevedo, A. A. Sorbello, G. P. S. Miguel, J. L. Wilson Jr., and A. C. d. Godoy, "Evaluation of tests performed to confirm the position of the Veress needle for creation of pneumoperitoneum in selected patients: a prospective clinical trial," Acta Cirurgica Brasileira, vol. 21, no. 6, pp. 385-391, 2006.

[4] S. Krishnakumar and P. Tambe, "Entry complications in laparoscopic surgery," Journal of Gynecological Endoscopy and Surgery, vol. 1, no. 1, pp. 4-11, 2009.

[5] G. A. Vilos, A. Ternamian, J. Dempster et al., "Laparoscopic entry: a review of techniques, technologies, and complications," 
Journal of Obstetrics and Gynaecology Canada, vol. 29, no. 5, pp. 433-447, 2007.

[6] O. H. M. Hypólito, J. L. M. C. Azevedo, F. M. S. De Lima Alvarenga Caldeira et al., "Creation of pneumoperitoneum: noninvasive monitoring of clinical effects of elevated intraperitoneal pressure for the insertion of the first trocar," Surgical Endoscopy, vol. 24, no. 7, pp. 1663-1669, 2010. 